\title{
INSECT RESISTANCE, ANIMAL TOXICITY AND ENDOPHYTE-INFECTED GRASS
}

D.L. GAYNOR and D.D. ROWAN1 Entomology Division, 'Applied Biochemistry Division,

\section{Abstract}

Endophyte infection is widespread in grasses and in many instances is associated with insect resistance. This resistance appears to be due to chemical components produced in the infected grasses. Ryegrass, infected with Acremonium lolige endophyte contains peramine, a feeding deterrent to stem weevil, Listronotus bonariensis. Other examples of endophyte-associated insect resistance are discussed and the mechanisms of this insect resistance are briefly compared with those mechanisms implicated in producing animal toxicity problems.

Keywords: endophyte, insect resistance, ryegrass, tall fescue, insect feeding deterrents, animal toxins, alkaloids.

\section{INTRODUCTION}

Interest in endophytic fungi infecting grasses dates back to 1898 (Sampson 1933) while endophytes in New Zealand grasses were first reported in 1940 (Neill 1940, 1941). Many different grass species are now known to be infected, each with different endophytes (Clay et. al. 1985). Recent research indicates that endophytic infection in grasses is associated with both insect resistance and animal toxicity problems. This paper reviews the current knowledge on endophyte-linked insect resistance and compares the mechanisms of insect resistance with those producing animal toxicity.

\section{INSECTS}

Goldson (1979) first found seedlings of perennial ryegrass resistant to Argentine stem weevil. Field resistance was later demonstrated by Kain et al. (1982a,b) who recorded less adult feeding and fewer eggs and larvae. on resistant plants. The mechanism of this resistance was clarified when it was shown that the endophyte, $A$. loliae, was present in resistant ryegrass (Prestidge et al. 1982). Reduced adult feeding, oviposition and larval development have all since been linked to the presence of endophyte (Prestidge et al. 1982, Gaynur and Hunt 1983, Barker et al. 1984a,b).

Insect resistance from grass-endophyte associations has now been observed for some eight other insect species (Table 1) but not all such associations lead to insect resistance (Table 2). In some cases insects appear to prefer grasses infected with endophyte. This is true of stem weevil on ryegrass infected with a Gliocladium-like endophyte (Gaynor et al. 1983) and cereal aphid on tall fescue infected with a Phialophthora-like endophyte (Latch et al. 1985). Resistance can be species specific. Infected tall fescue is resistant to fall armyworm (Spodoptera jrugiperda) but is not resistant to southern armyworm (Spodoptera eridonia) (Johnson et al. 1985).

\section{MECHANISMS OF INSECT RESISTANCE}

Studies on the effect of resistant grasses on insect development implicate both feeding deterrence and antibiosis as resistance mechanisms. Reduced feeding of adult stem weevil on infected leaves of ryegrass and tall fescue suggests the presence of a feeding deterrent (Gaynor et al. 1983, Gaynor and Hunt 1983, Barker et al. 1983, 1984a). Using a choise bioassay based on plant extracts incorported into artificial diets, Rowan and Gaynor (1985) showed that infected ryegrass contains a feeding deterrent. This deterrent, named peramine $\left(\mathrm{C}_{13} \mathrm{H}_{17} \mathrm{~N}_{3} \mathrm{O}_{2}\right)$, has been isolated and deters adult weevil feeding at Ippm, a concentration comparable to that found in $A$. 
TABLE 1: Insect Resistance in Grasses Infected with Endophyte.

\begin{tabular}{|c|c|c|c|c|}
\hline Grasses & Endopyte & Common Name & Scientific & R eference \\
\hline Lolium perenne & Acremonium loliae & $\begin{array}{l}\text { Stem weevil } \\
\text { Sod webworm } \\
\text { Bluegrass billbug } \\
\text { Fall armyworm } \\
\text { Pasture mealybug } \\
\text { Corn leaf aphid }\end{array}$ & $\begin{array}{l}\text { Listronotus bonoriensis } \\
\text { Crambus spp. } \\
\text { Sphenophorus paruulus } \\
\text { Spodoptero frugiperda } \\
\text { Pseudantonina poae } \\
\text { Rhopalosiphum maidis }\end{array}$ & $\begin{array}{l}\text { Prestidge et al. } 1982 \\
\text { Funk et al. } 1983 \\
\text { Ahmad \& Funk } 1983 \\
\text { Clay et al. } 1985 \\
\text { Pearson (pers. comm.) } \\
\text { Johnson et al. } 1985\end{array}$ \\
\hline Festuca arundinacea & $\begin{array}{l}\text { Acremonium coenophiolum } \\
\text { (Epichloe typhina) }\end{array}$ & $\begin{array}{l}\text { Stem weevil } \\
\text { Cereal aphid } \\
\text { Corn leaf aphid } \\
\text { Fall armyworm } \\
\text { Greenbug } \\
\text { Large milkweed bug }\end{array}$ & $\begin{array}{l}\text { Listronotus bonariensis } \\
\text { Rhopalosiphum padi } \\
\text { Rhopalosiphum maidis } \\
\text { Spodoptero frugiperda } \\
\text { Schizaphis graminum } \\
\text { Oncopeltus fasciatus }\end{array}$ & $\begin{array}{l}\text { Barker et al. } 1983 \\
\text { Latch \& cl. } 1985 \\
\text { Johnson \& al. } 1985 \\
\text { Clay et al. } 1985 \\
\text { Siegel et al. } 1985 \\
\text { Siegel et al. } 1985\end{array}$ \\
\hline $\begin{array}{l}\text { Cyperus virens } \\
\text { Cyperus pseudouegetus } \\
\text { Paspalum dilatatum }\end{array}$ & $\begin{array}{l}\text { Balansia cyperii } \\
\text { Balansia cyperii } \\
\text { Myriogenospora }\end{array}$ & $\begin{array}{l}\text { Fall armyworm } \\
\text { Fall armyworm }\end{array}$ & $\begin{array}{ll}\text { Spodoptero } & \text { frugiperdo } \\
\text { Spodoptera } & \text { frugiperdo }\end{array}$ & $\begin{array}{l}\text { Clay et al. } 1985 \\
\text { Clay et of. } 1985\end{array}$ \\
\hline $\begin{array}{l}\text { Stipa leucotricha } \\
\text { Cenchrus echinatas }\end{array}$ & $\begin{array}{l}\text { atramentrosa } \\
\text { Atkinsonella hypoxylon } \\
\text { Balansia obtecta }\end{array}$ & $\begin{array}{l}\text { Fall armyworm } \\
\text { Fall armyworm } \\
\text { Fall armyworm }\end{array}$ & $\begin{array}{ll}\text { Spodoptera } & \text { frugiperdo } \\
\text { Spodoptera } & \text { frugiperda } \\
\text { Spodoptero } & \text { frugiperda }\end{array}$ & $\begin{array}{l}\text { Clay et al. } 1985 \\
\text { Clay et al. } 1985 \\
\text { Clay et al. } 1985\end{array}$ \\
\hline
\end{tabular}


TABLE 2: Insects Not Affected by Grasses Infected With Endophyte.

\begin{tabular}{|c|c|c|c|c|}
\hline Grasses & Endophyte & Common name & Scientific name & Reference \\
\hline \multirow[t]{2}{*}{ Lolium perenne } & Acremonium loliae & $\begin{array}{l}\text { Cereal aphid } \\
\text { Rose-grain aphid } \\
\text { Strawberry aphid } \\
\text { English grain aphid }\end{array}$ & $\begin{array}{l}\text { Rhopalosiphum padi } \\
\text { Metopholophium dirhodum } \\
\text { Sitobion gragariae } \\
\text { Sitobion auenae }\end{array}$ & $\begin{array}{l}\text { Latch et al. } 1985 \\
\text { Latch et al. } 1985 \\
\text { Latch et al. } 1985 \\
\text { Johnson et al. } 1985\end{array}$ \\
\hline & Gliocladium-like & Stem weevil & Listronotus bonariensis & Gaynor et al. 1983 \\
\hline \multirow[t]{2}{*}{ Festuca arundinaceae } & Acremonium coenophialum & $\begin{array}{l}\text { Tobacco hornworm } \\
\text { Tobacco budworm } \\
\text { Southern armyworm } \\
\text { English grain aphid }\end{array}$ & $\begin{array}{l}\text { Manduca sexta } \\
\text { Heliothis virescens } \\
\text { Spodoptero eridonia } \\
\text { Sitobion avenae }\end{array}$ & $\begin{array}{ll}\text { Johnson et al. } & 1985 \\
\text { Johnson et al. } & 1985 \\
\text { Johnson et al. } & 1985 \\
\text { Johnson et al. } & 1985\end{array}$ \\
\hline & Phialophthora-like & Cereal aphid & Rhopalosiphum padi & Latch et al. 1985 \\
\hline Festuca rubra & Epichloe cf. typhina & Cereal aphid & Rhopalosiphum padi & Latch et al. 1985 \\
\hline
\end{tabular}


loliae-infected ryegrass. Cultures of A. loliae endophyte have recently been found to deter stem weevil feeding and preliminary results suggest they contain peramine (Rowan and Gaynor, unpublished data). This contrasts with results previously reported (Gaynor et al. 1983, Gaynor and Rowan 1985) and suggests that peramine is a fungal metabolite. Prestidge et $\mathrm{al}$. (1985) have also reported the presence of a stem weevil feeding deterrent from cultures of A. loliae but no pure material has been isolated by these workers.

Feeding deterrence is also implicated in the resistance of infected tall fescue to cereal aphid and greenbug (Latch et al. 1985, Siegel et al. 1985, Johnson et al. 1985). Both aphids quickly move off infected plants and die if caged on them. The basis of this feeding deterrence must be different from that affecting stem weevil because A. loliae-infected ryegrass is resistant to stem weevil but not cereal aphid or greenbug. Johnson et al. (1985) have shown that cereal aphids and greenbugs are deterred by extracts from infected seed which contain high levels of loline alkaloids. These alkaloids are present in high concentrations in infected tall fescue and in very low concentrations in uninfected tall fescue. They are reported to be absent from perennial ryegrass (Aasen et al. 1969). Although final proof that loline is a feeding deterrent for aphids is lacking, it is probable that two different classes of alkaloids (peramine and loline) are implicated as feeding deterrents.

As well as feeding deterrency, antibiosis and toxicity may be involved in endophyte related resistance. Stem weevil on infected ryegrass show reduced oviposition and larval development (Barker et al. 1984a,b). Stem weevil larvae reared on diet containcontaining lolitrem $\mathrm{B}$, a neurotoxin isolated from ryegrass infected with A. loliae, exhibit slower development rateś and higher mortality. However, lolitrem B is not a feeding deterrent to adult stem weevils (Prestidge and Gallagher 1985). Fall armyworm on infected ryegrass and tall fescue show reduced larval survival, weights and longer larval duration times (Clay et al. 1985). Extract from infected tall fescue seed was toxic to the large milkweed bug (Johnson et al. 1985). While reduced insect growth and increased mortality may also be due to reduced consumption resulting from the presence of afeedingdeterrent, the results of Prestidge and Gallagher (1985) indicate that antibiosis and/or toxicity are also likely to be involved in resistance.

\section{ANIMAL TOXICITY AND INSECT RESISTANCE}

Animal health problems have been reported for livestock grazing endophyte infected pasture. Stock grazing infected ryegrass are susceptible to ryegrass staggers (Fletcher and Harvey 1981) and cattle grazing infected tall fescue can suffer from a complex of disorders generally referred to as fescue toxicity (Bacon et al. 1977). Gallagher et al. (1981) reported the isolation of two potent lolitrem neurotoxins from staggers-producing ryegrass pasture. These lolitrems elicit staggers symptoms in mice and their presence in ryegrass has been linked to $\mathrm{A}$. loliae infection. The structures of lolitrem B $\left(\mathrm{C}_{42} \mathrm{H}_{55} \mathrm{NO}_{7}\right)$ and $\mathrm{C}\left(\mathrm{C}_{42} \mathrm{H}_{57} \mathrm{NO}_{7}\right)$ have been determined (Gallagher et al. 1984) and are structurally related to the known aflatrem, penitrem and janthitrem mycotoxins suggesting that they are produced by the endophyte (although this has yet to be proven).

A number of chemical constituents of tall fescue have been associated with fescue toxicity and these have been reviewed by Porter (1983). Butenolide A, ergot alkaloids, loline alkaloids and 4-aminobutyric acid have all been considered as possible causative agents but, largely due to the complexity of the fescue toxicity symptoms, no causative interactions have been proven. The loline alkaloids and 4-aminobutyric acid are present in higher concentrations in endophyte-infected plants but, while loline alkaloids reduce feed intake of rats their effect on cattle is not yet known. Ergot alkaloids can be produced in culture by the endophyte of tall fescue, A. coenophialum, and are suspected of causing gangrene symptoms in cattle, but so far fractionation of tall fescue 
extracts has not linked these compounds with fescue toxicity. Therefore the only compounds clearly linked to animal toxicity and the presence of endophyte are the lolitrems associated with ryegrass staggers.

\section{DISCUSSION}

Endophyte infection is widespread in grasses and in many instances is associated with insect resistance. This resistance appears to be due to chemical components present in the infected plants. Tall fescue infected with A. coenophialum contains loline alkaloids which have been implicated in both insect resistanceand fescue toxicity but are probably not the only factors involved.

Ryegrass infected with A. loliae endophyte contains at least two substances which adversely affect insects. Peramine is a feeding deterrent to adult stem weevils and appears to be very important in reducing the number of adult weevils and, hence, the number of eggs and larvae present on infected plants. Our preliminary results suggest that peramine is produced by the fungus. If this is confirmed then it would be necessary for endophyte to be present for resistance to occur. Lolitrem B is also present in infected ryegrass and appears to be toxic to stem weevil larvae. Lolitrem B differs chemically from peramine and is not a feeding deterrent to adult weevils. Therefore lolitrem B is probably less important than peramine in determining the resistance of infected ryegrass to stem weevil. Although lolitrem B is similar in structure to other fungal metabolites, there is no proof that it is produced by the fungus. In addition, the lolitrems are associated with causing ryegrass staggers whereas peramine has not been linked to any animal health problems.

The prospect of producing a ryegrass resistant to stem weevil without the undesirable side effect of ryegrass staggers depends on the production of infected ryegrass which contain peramine but not the lolitrems. If peramine and the lolitrems are both fungal metabolites then the next step will be the development of endophytic fungi that produce peramine but not the lolitrems.

Current research shows that the association of grass, endophyte, insects and livestock is very complex. The full extent of these interrelationships and their impact on agriculture remains to be determined.

\section{REFERENCES}

Aasen A.J.; Culvenor C.C.J.; Finnie, E.P.; Kellock, A.W.; Smith, L.W. 1969.

Aust. J. agric. Res. 20:71-86.

Ahmed, A.J.; Funk, C.R. 1983. J. Econ. Entom. 76: 414-416.

Bacon, C.W.; Porter, J.K.; Robbins, J.D.; Luttrell, ES. 1977. Appl. Environ. Microbiol. 34: 576.581 Barker, G.M.; Pottinger, R.P.; Addison, P.J. 1983. Proc. 36th N.Z. Weed Pest Cont. Conf.: 216.219 Barker, G.M.; Pottinger, R.P.; Addison, P.J.; Prestidge, R.A. 1984a. N.Z. J. agnc. Res. 27: 271-277. Barker, G.M.; Pottinger, R.P.; Addison, P.J. 1984b. Ibid: 279-281.

Clay, K.; Hardy, T.N.; Hammond, A.M. 1985. Oecologia 66: 1-5.

Fletcher, L.R.; Harvey, I.C. 1981. N.Z. vet. J. 29; 185-186

Funk, C.R.; Halisky, P.M.; Johnson, M.C.; Siegel, M.R.; Stewart, A.V.; Ahmed S.; Hurley, R.H.; Harvey, I.C. 1983. Bio/Technol. I: 189191 .

Gallagher, R.T.; White, E.P.; Mortimer, P.H. 1981. N.Z. vet. J. 29: 189-190

Gallagher, R.T.; Hawkes, A.D.; Steyn, P.S.; Vleggar, R. 1984.J. Chem. Soc., Chem. Commun. 614-616

Gaynor, D.L.; Hunt, W.F. 1983. Proc. N.Z. Grossld. Ass. 44: 257-263.

Gaynor, D.L.; Rowan D.D.; Latch, G.C.M.; Pilkington, S. 1983.

Proc. 36th N.Z. Weed Pest Cont. Conf.: 220-224.

Gaynor, D.L.; Rowan, D.D. 1985. Proc. 4th Aust. Conf. Grassld Invert. Ecol. In press.

Goldosn, S.L. 1979. Proc. 2nd Aust. Conf. Grassid Invert. Ecol. (Crosby, T.K.; Pottinger, R.P. Eds.). Government Printer: Wellington: 262-264.

Johnson, M.C.; Dahlman, D.L.; Siegel, M.R.; Bush, L.P.; Latch, G.C.M.; Potter, D.A.; Varney, D.R 1985. Appl. Environ. Microbiol. 49: 568.571.

Kain, W.M.; Wyeth, T.K.; Gaynor, D.L.; Slay, M. W. 1982a. N.Z. J. agric. Res. 25: 255.259.

Kain, W.M.; Slay, M.W.; Wyeth, T.K. 1982b. Proc. 3rd Aust Conf. Grassid. Invert. Ecol (Lee, KE Ed.). S.A. Govt. Printer: Adelaide: 265-271.

Latch. G.C.M.; Christensen, M.J.; Gaynor, D.L. 1985. N.Z. J. agric. Res. 28: 129-132. 
Neill, J.C. 1940. N.Z J Sci and Tech. A21: 280291

Neill J.C. 1941. Ibid A23: 185-193.

Prestidge, R.A.; Pottinger, R.P.; Barker, G.M. 1982. Proc. 35th N.Z. Weed Pest Cont Conf.:119-122

Prestidge, R.A.; Lauren, D.R.; Vander Zqpp, S.G.; Di Menna, M.E. 1985. N.Z. J. agric. Res. 28: 87.92

Prestidge, R.A.; Gallagher, R.T. 1985. Proc. 38th N.Z. Weed Pest Cont. Conf.: 38-40

Porter, J.K. 1983. Proc. Tall Fescue Toxicosis Workshop, Cooperative Extension Service, Uniu. Georgia College of Agriculture: 27-33.

Rowan, D D.; Gaynor, D.L. 1985. J. Chem. Ecol. In Press.

Sampson, K 1933. Trans. British Mycological Soc. 18: 337-343.

Siegel, M R.; Latch, G.C.M ; Johnson, M.C. 1985. Plant Diseases 69: 179.183. 